Article

\title{
Analysis of 19th and 20th Century Conservation Key Theories in Relation to Contemporary Adaptive Reuse of Heritage Buildings
}

\author{
Shabnam Yazdani Mehr \\ Faculty of Architecture, School of Engineering and Built Environment, Griffith University, Gold Coast QLD 4215, \\ Australia; shabnam.yazdanimehr@griffithuni.edu.au
}

Received: 9 February 2019; Accepted: 13 March 2019; Published: 18 March 2019

check for updates

\begin{abstract}
Heritage buildings are important in demonstrating the cultural identities of cities and, consequently, communities throughout the world. In the contemporary era, adaptive reuse has been considered as a strategy for protecting these buildings for both present and future generations. At present, the 19th and 20th century conservation and restoration theories are the backbone of the contemporary adaptation movement by introducing different forms of adaptive reuse over time. These theories revealed how the prioritization system for protecting heritage buildings has changed from a value base to technological needs and user demands. These theories have become theoretical guidelines and policies under modern development. However, these theories are less considered in the contemporary practice of adaptive reuse, and thus remain as theoretical guidelines and policies that are still being developed periodically in the national and international levels. The main aim of this study is to review and critically analyze principal 19th and 20th century theories of conservation, restoration, and adaptive reuse of heritage buildings in order to provide a holistic view of their application, aspects of which may be incorporated in future research, practice, and discussion on the subject. For this paper, these key theories are critically reviewed, analyzed, and discussed, contributing to the study of contemporary practice of adaptive reuse. A summary of the analysis of all key theories is presented. The analysis of the theories presents the evolution of different approaches to adaptive reuse of heritage buildings over time and shows the role of theories in the establishment of international conservation policies. The analysis further reveals the existing gap between theory and practice in contemporary adaptive reuse practice.
\end{abstract}

Keywords: key theories of conservation; restoration; adaptive reuse; heritage buildings

\section{Introduction}

Heritage buildings give identity to cities and consequently to communities, so these buildings should be preserved or reused for present and future generations [1]. Heritage buildings are evidence of traditions of a specific period of time, and, consequently, the responsibility of communities is to protect these buildings, as argued by Jokilehto [2]. The preamble of the Venice Charter [3] discusses the importance of heritage buildings, citing them as living witnesses of old traditions, and remaining for the present generation. This statement further implies the significance of preservation of heritage buildings for future generations. The importance of heritage buildings was also stated in the Nara Document: "the diversity of cultures and heritage in our world is an irreplaceable source of spiritual and intellectual richness for all humankind" [4] (p. 1). Jokilehto [2] believed that one of the most important reasons for conservation is the protection of community identity attached to a place. He further stated that identity is usually considered as a political tool and a motivation for making decisions regarding the restoration or destruction of a place. Lehne [5] believed that loss of heritage buildings results in the loss of social unity. 
While recognizing the ancient history of conservation across cultures, Plevoets and Van Cleempoel [6] and Wong [7] stated that the general lexicon related to modern conservation, restoration, and adaptation of heritage buildings emerged in the 19th century. For example, during the Renaissance, architects constructed new buildings while also adapting ancient structures. Preservation was usually carried out either to prolong the life of a heritage building or to make the building contemporaneously functional. Jokilehto [8] pointed out that buildings continuously experience different types of deterioration, including aging, weathering, and depletion by use. The level of building wear depends on structure, materials, and maintenance, so repair techniques may vary as a consequence based on different building cultures and technologies. However, the main aim of the repair and conservation of a heritage building, which is similar globally, is to keep and preserve the work of its original builder for both present and future generations. Throughout history, different theories related to the conservation and restoration of heritage buildings have emerged; however, most theories have placed an emphasis on maintaining a heritage building, with limited levels of intervention when necessary.

All selected principal theories for further study, either directly or indirectly, addressed adaptive reuse as a way of protecting heritage buildings, and thus different forms of adaptive reuse over time are identified. Although most principal conservation theories of the 19th and 20th centuries have been studied by previous authors [6-13], there are insufficient critical analyses of all prominent theories, or their role in the establishment of international conservation policies and consequently, in contemporary practice of adaptive reuse. Plevoets and Van Cleempoel [14] stated that review of adaptive reuse is mainly based on case study rather than architectural theory and conservation history. Furthermore, in the adaptation of heritage buildings, theory and practice are usually studied separately, despite theory and practice being connected to each other [15,16]. For example in Australia, the Burra Charter as a theoretical basis in the conservation of heritage buildings, is less understood and considered in adaptive reuse practice [17].

The main aim of this study is to critically analyze the evolution of prominent theories which have been selected for their important role in the development of international conservation and restoration policies in the course of history, as measured by their contribution to nationally or globally adopted standards, or recognition by the contemporaries or peers. The development of adaptive reuse as a contemporary concept in the protection of heritage buildings and their values is discussed. This paper contributes to the body of knowledge by not only reviewing a wide range of literature to show the evolution of prominent conservation and restoration theories of the 19th and 20th centuries, and their relationship to, and application in the contemporary practice of adaptive reuse, but also by exhibiting the evolution of adaptive reuse over time. These factors are less addressed by previous authors.

This paper starts with a terminology of concepts used in this paper. Then, the most significant theories are identified, discussed, and analyzed. The selected theories mainly cover three important movements, restoration, conservation, and restoration-conservation. The analysis of all prominent theories leads to the discussion of adaptive reuse. So, adaptive reuse as the most contemporary emerging discipline and strategy in the protection of heritage buildings is further discussed.

\section{Terminology}

Definitions of concepts of conservation, restoration, preservation, and adaptation by previous authors are summarized in Table 1. 
Table 1. Definition of different concepts used in this paper (Source: Author, 2019).

\begin{tabular}{|c|c|}
\hline Terms & Definitions \\
\hline Adaptation & $\begin{array}{l}\text { Any work to a building in order to change its function, performance, and capacity } \\
\text { (over and beyond maintenance) [18]. Modifying a place to suit proposed compatible use. } \\
\text { Modification is acceptable only when the adaptation has a minor effect on the cultural } \\
\text { significance of a place, and adaptation should include a minimum change to a significant } \\
\text { fabric, achieved only after considering options [19]. Adaptation means making minor } \\
\text { changes or considerably flexible changes [20], in terms of reversal potential. Adaptation } \\
\text { means adapting for another use, and sometimes seems the best way of preserving a } \\
\text { heritage building [21]. }\end{array}$ \\
\hline Conservation & $\begin{array}{l}\text { All the processes of looking after a place so as to retain its cultural significance. Includes } \\
\text { maintenance; may, according to circumstances, include preservation, restoration, } \\
\text { reconstruction, and adaptation; will commonly be a combination of more than one of } \\
\text { these }[19,22] \text {. Conservation is a way of caring for the natural and cultural significance of } \\
\text { a place to keep that significance [21]. }\end{array}$ \\
\hline Preservation & $\begin{array}{l}\text { Maintaining the structure of a building in its current state by slowing down its } \\
\text { deterioration }[19,20] \text {. Slowing down the deterioration of an existing building by applying } \\
\text { suitable repair methods. Preservation is "the act or process of applying measures necessary to } \\
\text { sustain the existing form, integrity and materials of a historic property" [23]. Keeping the } \\
\text { condition of the building even though some parts of the building are damaged, because } \\
\text { of their historical importance. Trying to avoid the high level of natural decay [24,25]. } \\
\text { Preservation is similar to maintenance, although it involves comprehensive works and } \\
\text { programs to both maintain the fabric and mitigate damage [21]. }\end{array}$ \\
\hline Restoration & $\begin{array}{l}\text { Returning the existing fabric of a place to the known earlier state by removing accretions, } \\
\text { or reassembling existing components without the introduction of new material [19]. } \\
\text { Returning the current structure of a building to a known former condition without using } \\
\text { new materials [20]. Restoration involves "reinstating the physical and/or decorative condition } \\
\text { of an old building to that of a particular date or event" [23]. The process of reverting the } \\
\text { building to its original condition. In this way, original materials, as well as techniques, } \\
\text { are used [24,25]. }\end{array}$ \\
\hline
\end{tabular}

Almost all heritage buildings may experience these applications in the course of their living history, and, in maintaining a building and its values for present and future generations and simultaneously making it usable, all these activities implemented on heritage buildings lead to a level of changes.

\section{Eugène Emmanuel Viollet-le-Duc (1814-1879)}

Eugène Emmanuel Viollet-le-Duc was the first principal inspector from the historic office "Service des Monuments Historiques" in France. His main contribution as an architect and inspector was in the restoration of heritage buildings since he had knowledge in traditional techniques and methods. Being involved in many restoration projects in France, Belgium, Netherlands, and Switzerland, Viollet-le-Duc became recognized as a leader of the restoration movement due to his direct or indirect influence on restoration [8].

The interventions proposed by Viollet-le-Duc for restoration works were usually extensive, and sometimes included inserting new physical elements into the building, although still in the original style [26]. Regarding reuse of historic buildings, Viollet-le-Duc stated [27] (p. 4):

" ... the best means of preserving a building is to find a use for it, and to satisfy its requirements so completely that there shall be no occasion to make any changes."

Viollet-le-Duc's theory focused on finding a suitable use for the restoration of the building, and also on preserving the spirit of time by considering the efforts of the original architect. As such, his theory on the restoration of historic buildings implied adaptation as well. Viollet-le-Duc adopted a clear, direct, and practical approach to restoring buildings, a viewpoint which has been applied by architects of subsequent eras. However, contrary to Viollet-le-Duc's assertion, finding a single suitable use for historic buildings does not necessarily preclude further restoration needs. User needs and 
requirements change over time, a phenomenon which can propel further restoration or adaptation of heritage buildings several times during their life cycle. Viollet-le-Duc further contended [27] (p. 4):

"In such circumstances, the best plan is to suppose one's self in the position of the original architect, and to imagine what he would do if he came back to the world and had the programme with which we have to deal laid before him."

Viollet-le-Duc believed that a restorer needs to act as an original architect and builder of a heritage building to restore the building to its original state. However, in the contemporary era and in practice, no-one can fully imagine him/herself in the position of the original architect. This imagined position may result in falsification and threaten intangible values of the building.

Viollet-le-Duc considered stylistic restoration in his practice [10,28] and noted [27]:

"The term Restoration and the thing itself are both modern. To restore a building is not to preserve it, to repair, or to rebuild it; it is to reinstate it in a condition of completeness which may never have existed at any given time."

By this statement, Viollet-le-Duc was asserting that the main duty of a restorer is to restore the whole building based on the time when it was constructed. As such, he indirectly focused on stylistic restoration. Plevoets [18] believed that Viollet-le-Duc's approach also encompassed "zeitgeist" theory. Zeitgeist is defined in the Oxford Dictionary [29] as "the defining spirit or mode of a particular period of history as shown by the ideas and beliefs of the time". Zeitgeist is further translated as "spirit of the age" or "spirit of the time", which was accepted broadly throughout the 20th century with the belief that the "spirit" of a specific time can be transferred through art and architecture [30]. Spirit of time/age can be perceived as an important feature of a heritage building by representing a specific time when a building was constructed, and requires consideration in adaptive reuse. Viollet-le-Duc further recognized the issue of availability of resources after the passing of an era in attempting to maintain a building's spirit of time/age. Furthermore, he believed that historic buildings need to be restored based on the perspectives of the original era of their construction rather than those of the restorer or architect who would operate in a subsequent era, although acknowledging that in each era of restoration available materials may not be original. This is an important matter in the restoration of heritage buildings in the contemporary era.

Viollet-le-Duc carried out various adaptation projects, such as the conversion of Saint-Martindes-Champs (a monastery) to a library. Through the adaptation process, Viollet-le-Duc considered the skills of the designer and believed that an architect should value the architectural harmony of a historic building and find ways to reduce the required changes for new uses as much as possible [8]. Thus, Viollet-le-Duc considered the original architect and architectural style in his work and tried to minimize alterations. Jokilehto [8] noted that Viollet-le-Duc placed an emphasis on maintenance of heritage buildings, stating: " ... however well done, the restoration of a building is always a regrettable necessity which intelligent maintenance must always prevent". Thus, according to Viollet-le-Duc, the priority was on maintenance of heritage buildings rather than their restoration. Stylistic restoration was introduced by Viollet-le-Duc, who is well known as a leader of the restoration movement in the 19th century.

\section{John Ruskin (1819-1900)}

During the 19th and 20th centuries, restoration and anti-restoration were a point of discussion and argument [18]. Anti-restoration was understood to focus on preservation of the original design of buildings within their own history and context, whilst restoration relied on a change to some parts of heritage buildings where necessary.

Viollet-le-Duc's theory on restoration received considerable criticism over time. In England, John Ruskin was one of the first leaders of the contemporary conservation movement and critics of Viollet-le-Duc's theory in stylistic restoration $[7,10]$. Ruskin, who considered restoration as something which could result in a falsification of history, thus proposed regular maintenance [31]. John Ruskin (1819-1900) [32] believed that the meaning of restoration was not fully understood, and he defined 
restoration as a destruction that a building could experience, which also result in the loss of historical authenticity. Ruskin further addressed simultaneously interventional and imitative restoration as an impossible process in protecting a heritage building [32] (pp. 162-182):

"It is impossible, as impossible as to raise the dead, to restore anything that has ever been great or beautiful in architecture.... . that spirit which is given only by the hand and eye of the workman, never can be recalled... And as for direct and simple copying, it is palpably impossible."

Ruskin considered a heritage building as a 'corpse' which could not be restored, but could be maintained. Ruskin believed every heritage building was a unique creation of an architect in a certain period of time, which could not be imitated or restored, but could be conserved. He indirectly implied 'zeitgeist' theory of spirit of time/age in his conservation theory because he considered age to be a contribution to the beauty of a heritage building, which must be conserved. As such, Ruskin considered age value. Ruskin further addressed restoration as a lie [32] (pp. 162-182):

"Do not let us talk then of restoration. The thing is a Lie from beginning to end.... Take proper care of your monuments, and you will not need to restore them."

He considered that restoration "was a lie from beginning to end" since heritage buildings were neglected first and then restored. Ruskin insisted on proper care of heritage buildings to prevent further restoration. So, Ruskin focused on and established the notion of conservation, giving rise to a theoretical approach which rejected the so-called destructive features of Viollet-le-Duc's restoration theory. Kuipers and de Jonge [28] stated that Ruskin emphasized protection, conservation, and maintenance of heritage buildings, and preferred true intervention rather than stylistic restoration. According to Powell [33], Ruskin believed that signs of the past, which were in the fabric of a heritage building, were irreplaceable. As stated by Burman [31], Ruskin gave priority to the identity and work of the first builder and architect who created the architecture, which also became an inspiration for the present architecture. Ruskin made a huge contribution to the preservation of historic buildings globally [31], and was titled a protector of heritage buildings [25]. In 1874, Ruskin rejected the gold medal of the Royal Institute of Architects, believing architects caused destruction in the guise of restoration [25]. Ruskin is recognized as the pioneer of conservation (anti-restoration) movement of the 19th century.

\section{William Morris (1834-1896)}

William Morris was one of the key persons in the conservation of heritage buildings in Britain in the late 19th century, who was mainly influenced by Ruskin [10,31]. In 1877, William Morris established the Society for Protection of Ancient Buildings (SPAB) in England [7], with an emphasis on heritage buildings as unique works of artists in a specific historic period, thus presenting the age of a building (akin to zeitgeist theory) [28]. The important unique features of a heritage building should not be removed or even restored, but preserved, even if a building's function changed [34]. Burman [31] believed that Ruskin was a motivation behind the establishment of the SPAB. The SPAB is one of the oldest organizations related to the historic places in the world. The SPAB put an emphasis on the repair and maintenance of heritage buildings rather than restoration [31]. The important attitudes of SPAB were "to put protection in the place of restoration" and "to stave off decay by daily care" [7]. Morris considered regular maintenance and repair as a way of conservation of heritage buildings. However, Morris proposed that repair with the minimum level of alteration in features would make a heritage building practical [34]. Morris as one of the writers of the 'Manifesto' for the SPAB explained the rejection of restoration in the draft. Morris believed that restoration of heritage buildings made the future generation reluctant to study them, since heritage buildings had experienced change based on the sense of the restorer and the spirit of their own time, and thus left history in the gap [31] (p. 60).

Morris put an emphasize on repair and preservation of heritage values rather than restoration [10]. Ruskin and Morris were advocates of fundamental changes in heritage buildings in response to changes in society [33]. The concept of value of an architecture was first introduced and considered by Ruskin and Morris, and then was further developed by Riegl [10]. Ruskin and Morris rejected stylistic 
restoration due to its purifying nature and believed that reproducing original styles in the form of restoration was an insult to the original architect of a heritage building.

\section{Camillo Boito (1836-1914)}

Camillo Boito established the Italian conservation movement, which proposed practical guidelines on the restoration and conservation of heritage buildings. Boito was a follower of Viollet-le-Duc's theory on restoration, and simultaneously admired Morris's restoration approach [35]. However, in 1884, Boito criticized both Viollet-le-Duc and Ruskin because he believed it was risky to put oneself in the place of the original architect and might result in falsification. He stated the best restoration practice could confirm the lie in restoration. Boito also criticized Ruskin's theory on conservation and stated that it is impossible to not touch a heritage building while restoring it, with the alternative being to let the building fall into disrepair [8].

Boito may not be well-known outside of Italy because his works were mostly not translated into English. His theory of conservation rejected the contrast between stylistic restoration and conservation focusing on separating levels of intervention, to keep all authentic layers of a historic building intact [22]. Boito classified architecture in three groups based on age: antique, medieval, and modern since the Renaissance [7]. He believed restoration and conservation should respect the features of each class [13]. Depending on the characteristics of a particular project, Boito applied three methodologies: "archaeological restoration" related to antique monuments, "picturesque restoration" related to medieval monuments, and "architectural restoration" related to Renaissance and other historic monuments [22] (p. 75). Boito also proposed eight methods to define what is old and what is new [22] (p. 76):

- Difference of style between the new and the old

- Difference of construction materials

- Suppression of profiles or decorations

- Exhibition of removed old pieces, installed next to the monument

- Engrave the date of restoration in each restored piece

- Descriptive epigraph carved on the monument

- Description and photographs of the different phases of the work, placed within the building or in a place close to it, or description printed in a publication

- $\quad$ Notoriety

These methods outline the need for distinguishing between old and new in the restoration of a heritage building, as well as preparing a clear and explicit documentation of any new works carried out on the building [7]. According to Plevoets [18], Boito did not directly state the need to reuse buildings and focused mainly on restoration and conservation, but his approach is applicable to reuse as well. Furthermore, Boito's theory of restoration can be interpreted broadly since in Italy the world "restauro" refers to "the action of returning something to a former owner, place, or condition" and also implies reconstruction and adaptation based on contemporary needs [18] (p. 48).

Boito pointed out an important difference between conservation and restoration. In restoration of heritage buildings, Boito's focus was mainly on "do as little as possible". As such, he preferred to restore some sections of a heritage building instead of an unnecessary restoration of the whole building [36]. He had a great contribution to the anti-restoration movement and focused on conservation by preventing a large number of unnecessary restorations [37]. Boito further expressed that the best way of conservation of heritage buildings was the maintenance of them and restoration should be considered as a "sad necessity", whilst a thoughtful maintenance should prevent restoration [22]. Boito's theory on the conservation of heritage buildings had an influential impact and provided a basis for the Athens Charter. The Athens Charter was the first international document to encourage modern conservation policy. Boito believed the method of the restoration of heritage buildings varied case by 
case [13], and restoration should be based on respecting the artistic and historic values of heritage buildings, whilst he considered alteration as untrustworthy [37].

Boito was a pioneer of restoration-conservation movement, in the late 19th and early 20th centuries, by addressing the approaches of both Viollet-le-Duc and Ruskin. He introduced three classes of age, stating the main of restoration-conservation is to respect to all these classes. Boito also proposed different ways in distinguishing between old and new, as an important factor in the restoration of a heritage building.

\section{Alois Riegl (1858-1905)}

During the first decade of the 20th century, Alois Riegl was general conservator of the Central Commission of Austria [38]. Riegl defined several values related to heritage monuments and categorized them into two groups of "memorial values" and "present-day value". The memorial values include: age value, historical value, and intended memorial values. The present-day value includes: use value, art value, relative art value, and newness value $[12,38,39]$. Riegl distinguished between age value and historical value and believed that age value is against the preservation of heritage buildings, whilst historical value is the result of faithful preservation of monuments [5,12,39,40]. Riegl [41] (pp. 15-37) stated that "[historical value] stand in irresolvable conflict with age-value only in those cases where copies are made to substitute for an original in all its historical and aesthetic aspects". These statements show the conflict between identified values by Riegl and further imply Riegl, to some extent, accepted stylistic/faithful restoration in heritage buildings in order to preserve their historic value. Lehne [5] (p. 71) stated that historic value was important during the 19th century, whilst age value was considered the main value during the 20th century, and "has the potential to dominate the future".

Riegl was the pioneer of making a systematic analysis of the concepts about the conservation of heritage buildings [2]. According to Bold et al. [42] (p. 13), Riegl believed that "every work of art is at once and without exception a historical monument. In the strictest sense, no real equivalent can ever be a substitute for it". Riegl considered heritage buildings as irreplaceable resources which must be protected.

Based on Riegl's theory, supporters of restoration of the time attempted to link newness value represented by a unique style, with historic value in terms of originality of style. The purpose was to remove all signs of decay and to restore every piece in order to create a historic object. In contrast, supporters of anti-restoration valued heritage buildings for their age value and believed the signs of decay needed to be retained to show that a heritage building had not been constructed recently [18].

According to Rouhi [13], Riegl rejected theories of "restoration" and "anti-restoration" believing that each heritage building belonged to a certain period, and thus for the preservation of a building the values of its period needed to be defined. This statement shows that Riegl's theory was in line with supporters of stylistic restoration in defining and preserving values of a heritage building with respect to a certain period when the building was constructed. Riegl believed that the preservation of heritage buildings was not restricted to their historical value, whilst age value was also required to be considered [12,41].

Riegl believed that "pure conservation" was impossible. He considered heritage buildings in all phases of their alteration. Riegl pointed out even cleaning of a painting was a modern intervention and also believed if it was possible for a heritage building to lose the visual elements of its decoration, reproduction of those features were justifiable [8]. Based on this statement, Riegl believed in the stylistic/faithful restoration to preserve endangered authentic features and heritage values of a building. However, according to Lehne [5] and Lamprakos [12], Riegl disapproved stylistic restoration and mainly focused on the age value of a building.

Riegl further recognized three categories of possible ways of restoration of wall paintings: "radical" referred to a minimum intervention with the aim of keeping the feeling of an old and decayed painting; "art-historical" implied priority on conservation and protection of the original painting as an evidence 
of the past; and "conservative" referred to completion and reconstruction of the original painting as it used to be [8]. Thus, Riegl placed priority on conservation and preservation of buildings and he considered restoration as a necessity in order to preserve a historic building, but with minimum levels of intervention. As such, Riegl addressed adaptive reuse indirectly by presenting different levels of intervention in heritage buildings.

Riegl believed that all humankind is responsible for the preservation and protection of heritage buildings. This belief is also reflected in the UNESC convention as the concept of the "common cultural heritage of humankind" [15] (p. 290). According to Falset et al. [15], Riegl's publications on heritage monuments and their protection are still relevant and applicable to the present situation and can be used for further study and discussion.

Riegl had an influential role in restoration and conservation of heritage buildings in the 20th century by introducing different values attached to a heritage building. Riegl distinguished the practice of restoration and conservation based on prioritizing between different values. His theories and definition of values are applicable to the contemporary practice of adaptive reuse of heritage buildings and the development of international conservation guidelines.

\section{The Athens Charter (1931)}

In 1931, The Athens Charter was prepared by the International Museum Office which was established after the First World War in order to study issues related to heritage conservation, heritage buildings restoration, and even restoration of an entire town which was destroyed or damaged during the war [8]. The Athens Charter was the first international document to encourage modern conservation policy [43]. The Athens Charter included seven solutions related to the restoration, preservation, and protection of heritage buildings and their surrounding neighborhood [7,44]. The Charter criticized "stylistic restoration" and supported regular and permanent maintenance, thus valuing the styles of all periods [37] (p. 28):

"When, as the result of decay or destruction, restoration appears to be indispensable, it recommends that the historic and artistic work of the past should be respected, without excluding the style of any given period. The Conference recommends that occupation of buildings, which ensures the continuity of their life, should be encouraged but that these buildings should be used for a purpose which respects their historic or artistic character".

The Athens Charter placed an emphasis on conservation of heritage buildings except in the situation when a building experienced decay or destruction and when restoration could be the most direct way of preserving the building and its authentic, historic, and artistic values.

The Athens Charter further expressed that it was important to preserve heritage buildings in their original location and respect their particular features. Under these circumstances, the use of modern technologies such as reinforced concrete was approved in order to preserve heritage buildings. Regarding ruined structures, the fragments could be replaced and new materials should be recognizable [45]. Thus, the Athens Charter indirectly implied adaptive reuse of heritage buildings as a way of making a building usable, and thus prevent its decay. By expressing 'the new materials should be recognizable', the Athens Charter stressed the alterations to a heritage building should be identifiable.

After the First World War, contemporary architects took the opportunity to apply their ideas in an individual and urban scale to design modern buildings, which was evident in the fourth CIAM (Congrès Internationaux d'Architecture Moderne) congress in 1933. The focus of the CIAM was on analysing the problems of 33 cities and proposing a serious of reports for the creation of a modern city [18]. Nevertheless, the CIAM congress also concluded how to address historic parts of cities [18] (p. 49):

"Historic objects (separate monuments or sectors of the city) must be retained:

- When its existence is not bought at the price of bad living conditions for the population that is compelled to live in it. 
- When the opportunity is afforded to remove its restricting influence on development by the diversion of traffic around it or the shifting of the focal point.

- An aesthetic adaptation of new parts of the city to the historic area has a catastrophic effect on the development of a city and is in no way to be desired. By the demolition of slum dwellings surrounding the historic monuments, green areas can be created, which improve the hygienic conditions in those areas".

Based on CIAM, heritage buildings needed to be preserved under specific conditions; firstly not being in a poor condition and people being forced to live in. Furthermore, according to CIAM, any aesthetic integration of new architecture into heritage buildings was firmly rejected. Currently, it is considered that an aesthetic synergy of a new architecture into a heritage building can add to the values of the building; however, this can be subjective. The outcome of CIAM resulted in the establishment of the Athens Charter 1933, which focused mainly on urban planning.

\section{Cesare Brandi (1906-1988)}

Cesare Brandi was an inspiration of the conservation theory and practice in Italy. His theory of conservation was strongly connected to the practice by proposing rational rules for the conservation and restoration methods [46]. In the early 1930s, Cesare Brandi (1906-1988) discussed restoration in art and architecture [47]. Brandi claimed that the restoration of a 'work of art' needs the identification of its specific aesthetic, historic, and 'claims'. He further put an emphasis on the aesthetic aspect to re-establish the potential integrity of the work [2]. According to Rouhi [13], Brandi introduced a critical restoration theory and developed his theory on careful restoration and conservation of heritage structures. Brandi considered different forms of restoration from 'simple respect' to 'radical operation' and believed the conflict in ideas about restoration was the result of this ambiguity. As stated by Matero [47] (p. 6), Brandi considered restoration as an act of critical interpretation and placed an emphasis on "reestablishment of the potential unity of the work of the art, as long as this is possible without producing an artistic or historical faux and without erasing the passage of time" [11] (p. 2). Thus, from Brandi's perspective restoration was a work of returning a heritage building to its original state without introducing artificial objects or even removing the signs of decay. According to Schädler-Saub [46], Brandi defined restoration-conservation as a methodology which starts with the identification of a work of art and its physical condition in its aesthetic and historical background, bearing in mind its transmission to the future.

Jokilehto [8] (p. 230) believed Brandi considered the construction material in a heritage building to be the result of human work, so using the same type of material for restoration of the building could provide "chemically the same material" but it presented a "different significance". Under these circumstances, restoration did not have the same meaning as the original and would become false historically and aesthetically [8]. However, on the contrary to Jokilehto, Mimoso [11] stated that Brandi believed that material could be sacrificed due to the importance of the aesthetic value of a heritage building. Schädler-Saub [46] believed that Brandi considered material as part of the artistic message of a work of art and it is an imperative responsible to preserve material which shows the artist's method in creation of the work of art.

Brandi considered architecture as a "work of art" which could be restored based on an aesthetic approach to the work [8] (p. 231). Brandi further stated that restoration must be limited to the original building and must be based on what was recommended by the conceivable harmony of the building in view of the needs of its aesthetic and historical features [8]. Thus, Brandi focused on historical and aesthetic values as important features in carrying out restoration of a heritage building. However, as stated by Matero [47], Brandi also considered functional performance as a driver of restoration depending on whether the work was 'industrial' or 'art'. Thus, Brandi's theory of restoration focused on the aesthetic, historical, and functional values of heritage buildings.

In 1963, Brandi further expressed three principles in relation to the restoration of a heritage building [8] (p. 236): 
- Any reintegration should be easily recognizable at close distance but, at the same time, it should not offend the unity that is being restored.

- A part of material that directly results in the building's image is irreplaceable since it forms the appearance and not the structure.

- Any restoration should be carried out in a way that it will not be an obstacle for necessary future interventions.

Brandi focused on a thoughtful restoration approach which enables further restoration work. He considered any restoration work must respect the original building, and thus must be identifiable. Brandi further believed some materials cannot be replaced due to their role in presenting the main features of a building. Thus, Brandi's theory on restoration implied conservation as well. Brandi defined the main aim of conservation is protecting a work of art [47]. According to Barassi [48], Brandi placed an emphasis on four important principles in the conservation of a heritage building:

- A conservator must not imitate an original architect's style or interpret the work subjectively, instead, a conservator must respect the time of creation of a work, and thus try to conserve a historic building based on its era.

- It is important to prevent interventions in the form of removing the signs of decay on a heritage building, which hide the real age of the building.

- Any conservation work on a historic building must be reversible.

- A conservator must plan conservation based on the specific needs and condition of the work. Thus, the conservator must have knowledge about a historic building.

Brandi defined the entire conservation work based on three categories: physical form and fabric, history, and context, which must be recognizable even after alteration. Thus, "loss and compensation" were an important concern to Brandi, which were considered significant issues in the conservation of art and architecture [47] (p. 46). Wong [7] stated that Brandi's theory was internationally recognized in the development of conservation policies and UNESCO missions.

Brandi was the 20th century theorist who addressed modern restoration-conservation movement. He mainly focused on aesthetic and historic values in the restoration and conservation of heritage buildings. His theories and approaches have had an influential role in the development of international conservation policies nationally and internationally.

\section{The Venice Charter (1964)}

Conservationists tried to conserve the remaining historic buildings of the post-war era and to adapt them based on the needs of the modern world, although some architects considered heritage buildings as an obstacle to further development. In the 1960s, a movement happened in which architects and conservationists worked together since some architects showed interest in working on heritage buildings [18].

The term 'historic' was limited to antique and medieval buildings up to the 19th century, but following the destruction of the Second World War, there was an increase in consciousness related to the values of heritage buildings and interest in different building typologies which were valuable for preservation [18]. In 1964, following the Second Congress of Architects and Specialists of Historic Buildings in Venice, the Venice Charter as the international restoration charter, and ICOMOS as the international council on monuments and sites were established [49]. The Venice Charter is a post-war document which played an important role in the history of conservation [50]. In the Venice Charter, a review of conservation theory was developed in which adaptive reuse was introduced as a form of conservation practice [18] (p. 50):

"The conservation of monuments is always facilitated by making use of them for some socially useful purpose."

The Venice Charter considered the community as a driving force for conservation of heritage buildings and thus placed a priority on social usefulness of buildings. It can be seen that for the 
conservation and adaptation of heritage buildings, social factors have been considered by many authors and theorists.

The Venice Charter was based on a revision of the 1931 Athens Charter and focused on a discussion about the conservation and restoration of heritage buildings [8]. The Venice Charter distinguished between conservation and restoration by stating that the purpose of conservation is to maintain, while the main aim of restoration is to address the historic and aesthetic value of a monument. The Venice Charter had a major role in the development of international conservation policies such as the Australian Burra Charter [7].

The Venice Charter, as an international document, developed after the Second World War and covered modern conservation movement. The charter directly introduced adaptive reuse as a way of conserving a heritage building.

\section{Adaptive Reuse}

Powell [33] stated that the origin of transformation in architecture, regardless of preservation, emerged in the 19th century. Changing buildings to other functions and uses has occurred throughout history, although adaptive reuse as theory and practice has only been formalized since the 1970s [18]. The act of converting existing buildings to a new function is not new, since in the past, structurally sound buildings were changed to fit new functions or changed requirements, with little concern or questioning. As an example, during the French Revolution, religious buildings which had been confiscated and sold, were altered to military or industrial uses [51]. However, in most cases, the interventions were carried out on a needs basis with little conscious consideration for preserving heritage [18]. Powell [33] believed functional and financial factors were driving forces which promoted adaptive reuse, and stated that legislation, in terms of protecting heritage buildings, emerged only in the 19th century. Cantacuzino [52] was one of the first authors to describe the practice of adaptive reuse. He put an emphasis on the structural durability of old buildings as the main driver for their adaptation over time, and believed adaptation and preservation of existing buildings in an urban context over time led to a strengthened feeling of belonging throughout societies [52] (p. 8):

"Because structure tends to outlive function, buildings throughout history have been adapted to all sorts of new uses. Except when the cataclysm of natural forces or war wreaked wholesale destruction, change in the urban fabric was slow, which enabled generation after generation to derive a sense of continuity and stability from its physical surroundings."

In 1995, Brand gave a detailed discussion in relation to adaptive reuse [53], paving the way for contemporary practice. He believed that technology, fashion, and money are three strong reasons for adaptation [53]. Although the main focus of Brand was on all existing buildings, these factors are critical in making decisions related to adaptive reuse of heritage buildings in the contemporary era. The Brand approach to adaptive reuse further shows how the purpose of adaptive reuse of heritage buildings has changed over time from preservation of values to financial grounds, and now to technology improvements. In the contemporary practice of adaptive reuse, the focus is on technical upgrades of a heritage building without compromising of its heritage values. However, the priority is mostly on preserving heritage values.

De Arce [54] believed that use and reuse of heritage buildings play an important role in urban development by improving the quality of a town through various factors, including prolonged use of existing buildings, decreased cost of material because of recycling, creating a spatial and historical sense of place, and continuing the routine way of life. De Arce did not consider the needs and requirements of society or recognize the need to preserve the historical and architectural values of buildings for adaptive reuse. However, these features are of paramount importance with regard to heritage buildings. Adaptive reuse has been defined by many authors $[7,18,21,23,55-58]$ who have claimed it is a spectrum of changes, from maintaining a building due to its heritage values to changing the function of a building for other uses, either partially or wholly. As such, the adaptive reuse concept 
covers all concepts discussed in this paper, including conservation, restoration, preservation, and even maintenance of heritage buildings.

In the contemporary era, adaptive reuse has been mainly discussed in two forms, within-use adaptation, and across-use adaptation $[56,57,59,60]$. Through within-use adaptation, a building experiences adaptation based on its primary function. In across-use adaptation, a building undergoes extensive adaptation in the form of functional changes. Comparing these contemporary perspectives with those of the 19th and 20th centuries, theorists mostly addressed within-use adaptation and introduced some degree of interventions in a heritage building based on its primary function. Across-use adaptation formally emerged from the Venice Charter referring to functional changes in a heritage building.

\section{Analysis of Theories}

This analysis of 19th and 20th century key-theories shows the evolution of the adaptive reuse concepts in the course of history. Key theories are mainly presented in three groups, the stylistic restoration, conservation (anti-restoration), and restoration-conservation movements, and thus these theories cover a wide range of activities on heritage buildings. These theories have played a fundamental role in the development of national and international conservation policies and legislations. Table 2 shows the evolution of key theories over time.

Table 2 shows that theorists either directly or indirectly considered adaptive reuse by addressing different levels of intervention and alteration in heritage buildings; however adaptive reuse has been self-consciously addressed since the 1970s. Generally, theorists put an emphasis on thoughtful and careful maintenance and conservation rather than restoration. However, Scott [25] believed that the continuous maintenance of a heritage building is to some extent restoration. In the contemporary era, this is impossible to just focus on maintenance due to changes in user demands and advances in technology. These contemporary changes necessitate some levels of adaptation in heritage buildings especially for those which are still in use.

The evolution of these principal theories shows that although the main concern of the 19th century theories was restoration or conservation of heritage buildings, the 20th century theories introduced values and defined restoration and conservation based on values attached to a heritage building. Familiarity with these values have had a major role in the development of contemporary international policies and legislation related to heritage buildings. However, the contemporary practice of adaptive reuse is almost based on new criteria rather than values. This new criterion is the result of advances in technology and changes in user demands. As such, although these theories are important in the practice of adaptive reuse, they usually remain as theoretical guidelines and are less considered in practice.

The analysis of theories since the 19th century revealed that there was a controversial debate between theorists regarding restoration and conservation of heritage buildings. Some theorists believed in the stylistic/faithful restoration of heritage buildings. Stylistic restoration refers to considering the original style of a heritage building in any work carried out to the building. Bold et al. [42] used the term 'historicist reconstruction', which may be a synonym to stylistic restoration. They believed that historicist reconstruction aims to prevent the unavoidable processes of time and decay. 
Table 2. Evolution of key theories over time (Author, 2019).

\begin{tabular}{|c|c|c|}
\hline Theorists & Time Frame & Importance of Theories \\
\hline Viollet-le-Duc & $\begin{array}{l}\text { 19th century-after the } \\
\text { French Revolution }\end{array}$ & $\begin{array}{l}\text { - } \quad \text { Pioneer of stylistic restoration movement. } \\
\text { - } \quad \text { Finding a proper use for heritage buildings to avoid further changes in future. } \\
\text { - } \quad \text { Insertionstatement of a heritage building in a condition of completeness. } \\
\text { - } \quad \text { Posiginal style. }\end{array}$ \\
\hline Ruskin & 19th century-Victorian era & $\begin{array}{l}\text { - } \quad \text { Critic of Viollet-le-Duc approach in terms of the stylistic restoration. } \\
\text { - } \quad \text { Leader of conservation (anti-restoration) movement. } \\
\text { - } \quad \text { Focus on the daily care of heritage buildings. }\end{array}$ \\
\hline Morris & $\begin{array}{l}\text { 19th century-Victorian } \\
\text { era-follower of Ruskin }\end{array}$ & $\begin{array}{l}\text { - } \quad \text { Follower of Ruskin's approach to conservation of heritage buildings. } \\
\text { - } \quad \text { Preservation of a unique work of artists in a specific historic period. } \\
\text { - } \quad \text { Main focus on repair and maintenance. } \\
\text { - Preservation of the important unique features of a heritage building even if the } \\
\text { function changes. } \\
\text { Founder of the Society for the Protection of Ancient Buildings (SPAB) which is } \\
\text { the oldest organization in the world related to preservation of historic places. }\end{array}$ \\
\hline Boito & $\begin{array}{l}\text { 19th and early 20th } \\
\text { century—reconciliation of } \\
\text { Viollet-le-Duc's and Ruskin's } \\
\text { movement-inspiration of } \\
\text { modern conservation policies }\end{array}$ & $\begin{array}{l}\text { - Pioneered the restoration-conservation movement by addressing both } \\
\text { Viollet-le-Duc and Ruskin's approaches related to heritage buildings. } \\
\text { Introduced three classes of age and stated the main aim of restoration is to } \\
\text { respect all these classes. } \\
\text { - Proposed different ways of distinguishing between old and new, as an important } \\
\text { factor in the restoration of a heritage building. } \\
\text { - Separated levels of intervention to keep all authentic layers of a heritage } \\
\text { building intact. } \\
\text { Restoration of heritage buildings varies case by case and must respect authentic } \\
\text { features and heritage values of a building. }\end{array}$ \\
\hline Riegl & 19th and early 20th century & 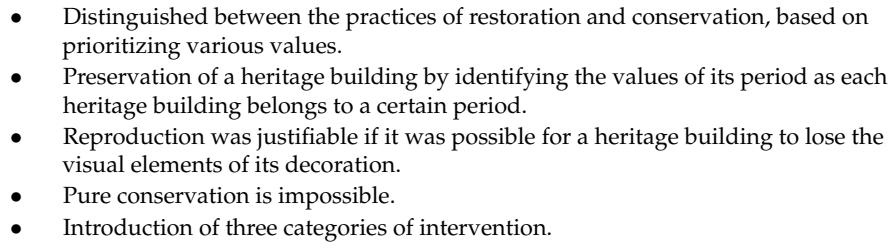 \\
\hline $\begin{array}{c}\text { Athens Charter } \\
1931\end{array}$ & $\begin{array}{l}\text { 20th century-1st International } \\
\text { Congress of Architects and } \\
\text { Technicians of Historic } \\
\text { Monuments-first international } \\
\text { document on heritage } \\
\text { conservation policies after } \\
\text { the WWI }\end{array}$ & $\begin{array}{l}\text { - The first international document addressing restoration of heritage buildings as } \\
\text { - } \quad \text { Crit as modern conservation movement. } \\
\text { - } \quad \text { Supporting regular as well as permanent maintenance, and conservation. } \\
\text { - } \quad \text { Preservation of a heritage building and its authentic features and heritage values. } \\
\text { - } \quad \text { Restoration of a heritage building when the building experienced decay } \\
\text { or destruction. } \\
\text { - } \quad \text { Ruined structure of a heritage building must be replaced by } \\
\text { identifiable materials. } \\
\text { - Considering restoration as a way of retaining a heritage building usable; } \\
\text { however, it should be recognizable. }\end{array}$ \\
\hline Brandi & 20th century & $\begin{array}{l}\text { - } \\
\text { - } \quad \text { Returning a heritage building to its original state without introducing artificial } \\
\text { objects or removing the signs of decay. } \\
\text { - } \quad \text { Preservation of historical, functional, and aesthetic values of a heritage building. } \\
\text { - Thoughtful restoration must respect the original building and be identifiable. } \\
\text { Respecting to a heritage building's original era through conservation, not imitate } \\
\text { an original style and not removing signs of decay, not hide the real age of a } \\
\text { heritage building. } \\
\text { Influential role in the restoration and conservation practice and the development } \\
\text { of international conservation policies. }\end{array}$ \\
\hline Venice Charter & $\begin{array}{l}\text { 20th century-post WWII } \\
\text { document on conservation } \\
\text { and restoration }\end{array}$ & $\begin{array}{l}\text { The international document, covered conservation movement and directly } \\
\text { introduced adaptive reuse as a way of conserving a heritage building. } \\
\text { - Conservation of a heritage building was considered as a strategy to make the } \\
\text { building practical. } \\
\text { - Consideration of architectural integrity and historical authenticity of a } \\
\text { heritage building. }\end{array}$ \\
\hline
\end{tabular}

Tomaszewski and Polistampa [16] stated that stylistic restoration was accepted during the 19th century. They believe that this theory resulted in the destruction of heritage buildings in terms of restoring their stylistic features, and consequently, new conservation theories developed to protect 
heritage buildings. However, the practice of stylistic restoration is still viable among conservators and architects globally. Advocates of stylistic restoration [27,39] believed that a heritage building must be restored to its original time when the building was constructed and all signs of decay need to be removed. They believed in the historical value of heritage buildings rather than age value. Thus, they put an emphasis on a specific period of time and restoration of authentic features and heritage values with respect to that era. Furthermore, the supporters of stylistic restoration believed to some extent that restoration must be carried out on a heritage building with the same harmony and exact materials as the original. Some theorists rejected stylistic restoration of heritage buildings [22,61,62], stating that all signs of decay must be preserved to show the real age of a heritage building, and thus considering the age value of a heritage building. This belief included that removing signs of decay creates a counterfeit feeling related to heritage buildings related to age. Thus, subscribing theories focused mainly on preserving signs of decay and all past works carried out on heritage buildings to show the real age of a building. Those theorists believed using different materials shows the distinguishability between old and new, which is important in conveying the true feeling of a place. Furthermore, all past works carried out on a heritage building become part of a building's history over time, and thus add to the building's values. Although stylistic restoration is perceived to be the main focus of the 19th century and thus has been criticized by many theorists and charters such as the Athens Charter and Australian ICOMOS, the practice of stylistic restoration remains viable among conservators and architects globally. For example, South Brisbane Municipal Chambers in Australia experienced seven different functions during its lifecycle. The contemporary adaptation of the building was in the form of stylistic restoration through restoring all components to their original state (Figures 1 and 2).

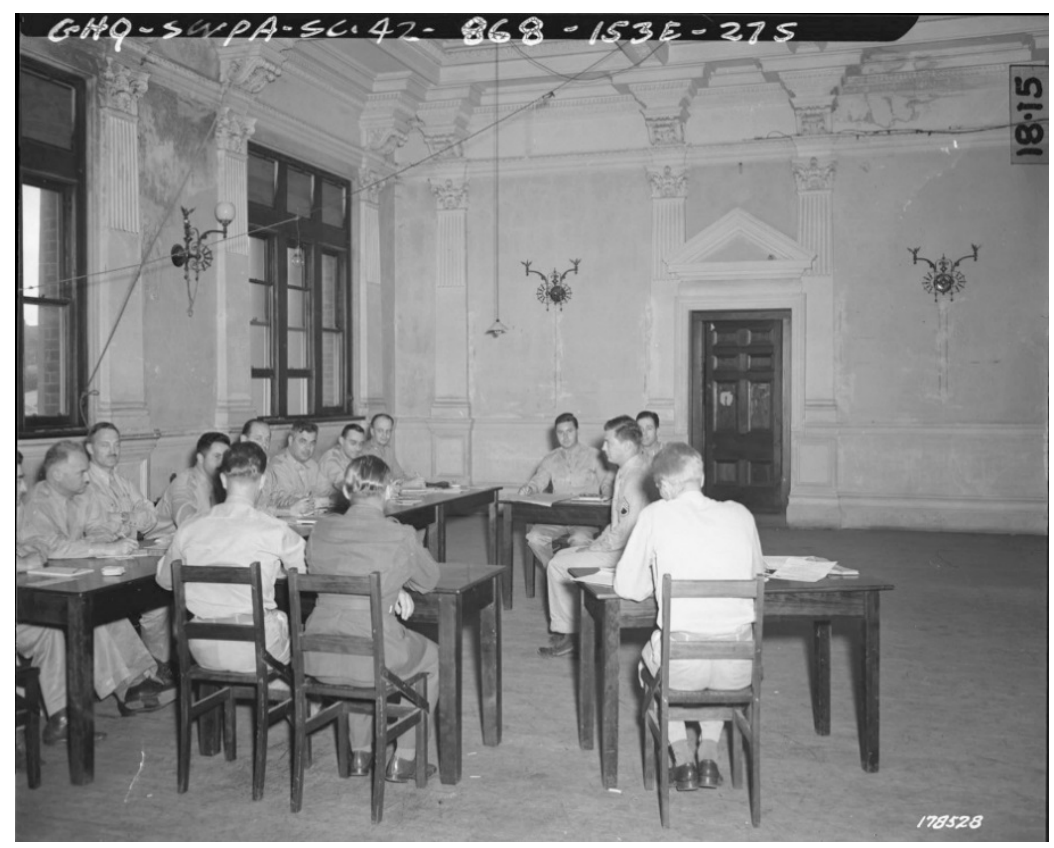

Figure 1. South Brisbane Municipal Chambers during the Second World War 1943 \& 1944 (Source: The National Archives in Washington DC).

Figures 1 and 2 are further evidence of the existing gap between theory and practice. Although numerous conservation guidelines and legislations are being developed nationally and internationally, these are less considered in contemporary adaptive reuse practice. 


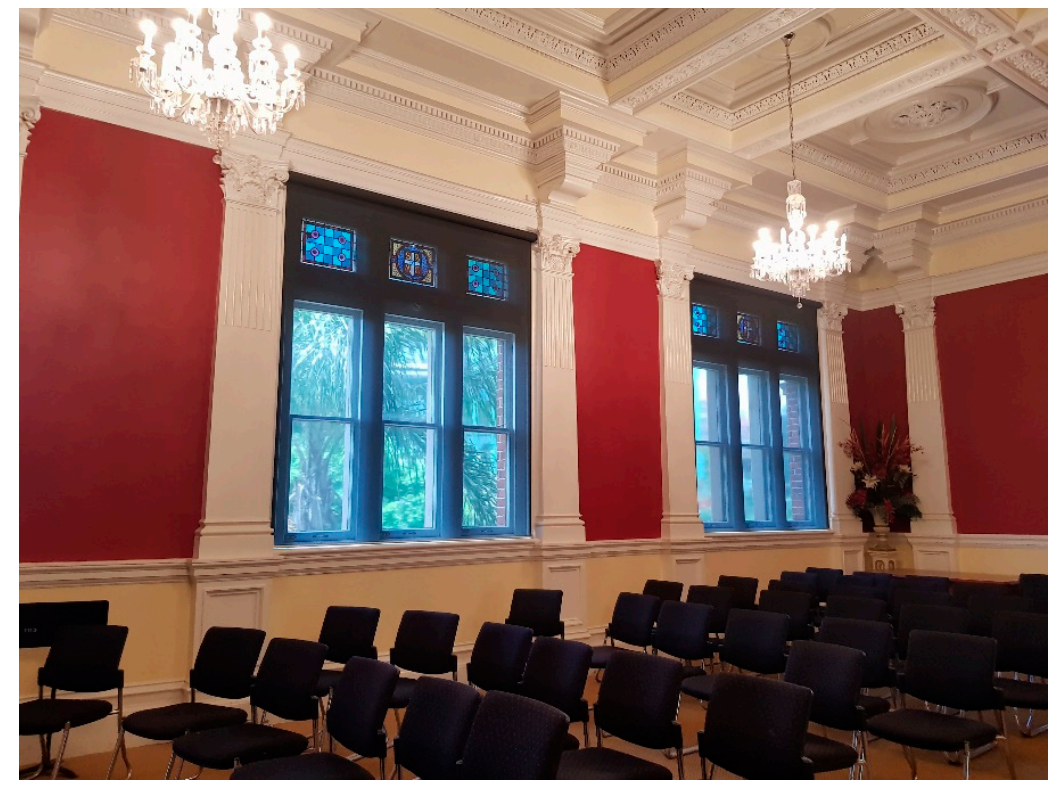

Figure 2. South Brisbane Municipal Chambers in 2018 (Source: Author, 2018).

\section{Conclusions}

In this paper, the evolution of prominent conservation theories of the 19th and 20th centuries and their relationship with, as well as their application to, the contemporary practice of adaptive reuse were discussed and critically analyzed. All prominent theories of the 19th and 20th centuries introduced different approaches to adaptive reuse by introducing different levels of intervention in practice. In the contemporary era, adaptive reuse has been presented as a strategy which covers and justifies almost all activities carried out on heritage buildings, and consequently include restoration, conservation, and even maintenance. The evolution of theories further reveals how the prioritization system for protecting heritage buildings has changed from a value base to technological needs and user demands. However, at the present time, the consideration is given to technical upgrades of a heritage building without compromising its heritage values as much as possible.

It is clear that there are different perspectives on the adaptive reuse of heritage buildings and different experts apply different theories, depending on Philosophy, country, culture, and heritage policies. Considering spirit of place and spirit of time/age as part of authentic features and values of a heritage building, a debate still remains in terms of which theory or theories are reliable and applicable in the contemporary era; stylistic restoration of a heritage building with the same materials or preservation of all signs of decay and past works carried out on a heritage building and restoration of the building with different materials. Keeping intact remnants of past works carried out on heritage buildings throughout history can show different historical layers of a building. As stated by Powell [33], a multi-layered historical building is a gift from the past. This sentiment is reinforced by Plevoets [18], who considered that the connection of the different historical layers of a building can enhance the depth and richness of its memory, and thus contributes to the spirit of a place. However as stated by Jokilehto [2], some may sacrifice the patina of age for the continuous use of a heritage building, thus consider stylistic restoration.

Although numerous theories are, to some extent, related to adaptive reuse, most of them have not been taken into account related to practice of adaptive reuse. This paper lifts our awareness of potential underpinning theories related to the conservation, restoration, and adaptation of heritage buildings. Comprehending these theories paves the way for scholars, experts, and students to strengthen research and practice in adaptive reuse of heritage buildings by incorporating the theoretical position that underpins their work. 
Funding: This research received no external funding.

Acknowledgments: I would like to thank Gordon Holden for his comments on this paper.

Conflicts of Interest: The author declares no conflict of interest.

\section{References}

1. Jacobs, J. The Life and Death of Great American Cities; Random House: New York, NY, USA, 1961.

2. Jokilehto, J. The idea of conservation: An overview. In Conservation and Preservation: Interactions between Theory and Practice: In Memoriam Alois Riegl (1858-1905): Proceedings of the International Conference of the ICOMOS International Scientific Committee for the Theory and the Philosophy of Conservation; Polistampa: Vienna, Austria, 2008; pp. 1000-1015.

3. Venice Charter, R. International Charter for the Conservation and Restoration of Monuments and Sites; (Adopted by in ICOMOS 1965); ICOMOS: Venice, Italy, 1964.

4. ICOMOS The Nara Document on Authenticity; ICOMOS (International Council on Monuments and Sites): Nara, Japan, 1994.

5. Lehne, A. Georg dehio, alois riegl, max dvorák-A threshold in theory development. In Conservation and Preservation: Interactions between Theory and Practice: In Memoriam Alois Riegl (1858-1905): Proceedings of the International Conference of the ICOMOS International Scientific Committee for the Theory and the Philosophy of Conservation; Polistampa: Vienna, Austria, 2008; pp. 1000-1012.

6. Plevoets, B.; Van Cleempoel, K. Adaptive Reuse as a Strategy towards Conservation of Cultural Heritage: A Survey of 19th and 20th Century Theories. In Proceedings of the Reinventing Architecture and Interiors: The past, the present and the future, Greenwich, UK, 29-30 March 2012.

7. Wong, L. Adaptive Reuse: Extending the Lives of Buildings; Birkhäuser: Basel, Switzerland, 2016.

8. Jokilehto, J. History of Architectural Conservation; Routledge: London, UK, 2007.

9. Schmukle-Mollard, C. Viollet-le-duc and his followers. French theories in the 19th and the 20th centuries. In Conservation and Preservation: Interactions between Theory and Practice. In memoriam Alois Riegl (1858-1905); Polistampa: Vienna, Austria, 2010; pp. 37-45.

10. Niglio, O. John Ruskin: The Conservation of the Cultural Heritage; Kyoto University: Kyoto, Japan, 2013.

11. Mimoso, J. Cesare Brandi's Theory of Restoration and Azulejos; Laboratório Nacional de Engenharia Civil (LNEC): Lisboa, Portugal, 2009.

12. Lamprakos, M. Riegl's "modern cult of monuments" and the problem of value. Chang. Time 2014, 4, 418-435. [CrossRef]

13. Rouhi, J. Development of the Theories of Cultural Heritage Conservation in Europe: A Survey of 19th and 20th Century Theories. In Proceedings of the 4th International Congress on Civil Engineering, Architecture \& Urban Development, Tehran, Iran, 27-29 December 2016.

14. Plevoets, B.; Van Cleempoel, K. Adaptive reuse as a strategy towards conservation of cultural heritage: A literature review. Struct. Stud. Repairs Maint. Herit. Archit. 2011, 12, 155-164.

15. Falser, M.; Lipp, W.; Tomaszewski, A. Conservation and preservation, interactions between theory and practice in memoriam Alois Riegl (1858-1905). In Proceedings of the International Conference of the ICOMOS International Scientific Committee for the Theory and the Philosophy of Conserviation and Restoration, Vienna, Austria, 23-27 April 2008.

16. Tomaszewski, A.; Polistampa, E. Values and critera in heritage conservation. In Proceedings of the International Conference of ICOMOS, ICCROM, Fondazione Romualdo Del Bianco, Florence, Italy, 2-5 March 2007.

17. Marshall, D. The burra charter in an international context-The implications of international doctrine for practice in Australia. In Conservation and Preservation: Interactions between Theory and Practice: In Memoriam Alois Riegl (1858-1905): Proceedings of the International Conference of the ICOMOS International Scientific Committee for the Theory and the Philosophy of Conservation; Polistampa: Vienna, Austria, 2008; pp. 1000-1007.

18. Plevoets, B. Retail-Reuse: An Interior View on Adaptive Reuse of Buildings. Ph.D. Thesis, Hasselt University, Hasselt, Belgium, 2014.

19. ICOMOS. The Burra Charter: The Australia ICOMOS Charter for Places of Cultural Significance 2013; Incorporated Peter Marquis-Kyle: Brisbane, Australia, 2013. 
20. Department of Planning Sydney. Heritage Assessment Guidelines; (Crown Copyright: 1995); Office of Environment and Heritage: Sydney, Australia, 1995.

21. Aplin, G. Heritage: Identification, Conservation, and Management; Oxford University Press: Oxford, UK, 2002.

22. Boito, C.; Birignani, C. Restoration in architecture: First dialogue. Future Anterior 2009, 6, 68-83. [CrossRef]

23. Douglas, J. Building Adaptation; Routledge: London, UK, 2006.

24. Brooker, G.; Stone, S. Rereadings: Interior Architecture and the Design Principles of Remodelling Existing Buildings; RIBA Enterprises: Newcastle, UK, 2004.

25. Scott, F. On Altering Architecture; Routledge: London, UK, 2007.

26. Vaccaro, A. Restoration and anti-restoration. In Historical and Philisophical Issues in the Conservation of Cultural Heritage. The Getty Conservation Institute: Los Angeles, CA, USA, 1996; pp. 308-313.

27. Viollet-le-Duc, E.-E. Dictionnaire Raisonné de l'Architecture Française du Xie Au Xvie Siècle; English Edition on Restoration (London, 1875); B. Bance: Paris, France, 1854.

28. Kuipers, M.C.; de Jonge, W. Designing from Heritage: Strategies for Conservation and Conversion; TU Delft-Heritage \& Architecture: Delft, The Netherlands, 2017.

29. Online Oxford Dictionary D. Oxford English Dictionary; Oxford University Press: Oxford, UK, 2018.

30. A Dictionary of Modern Architecture [Internet]. University of Chicago. 2015. Available online: https: / /voices.uchicago.edu/201504arth15709-01a2/2015/11/16/z/. (accessed on 15 March 2019).

31. Burman, P. Ruskin's children: John ruskin (1819-1900), the good steward, and his influence today. In Conservation and Preservation: Interactions between Theory and Practice: In Memoriam Alois Riegl (1858-1905): Proceedings of the International Conference of the ICOMOS International Scientific Committee for the Theory and the Philosophy of Conservation; Polistampa: Vienna, Austria, 2008; pp. 1000-1021.

32. Ruskin, J. The lamp of memory (1849). Hist. Perspect. Prev. Conserv. 1849, 6, 2.

33. Powell, K. Architecture Reborn: The Conversion and Reconstruction of Old Buildings; Calmann \& King Ltd.: London, UK, 1999.

34. Yount, A. William Morris and the Society for the Protection of Ancient Buildings: Nineteenth and Twentieth Century Historic Preservation in Europe. Ph.D. Thesis, Gradute College at Scholarworks at Western Michigan University, Lansing, MI, USA, June 2005.

35. Umar, S.B. A Conservation Guideline for Traditional Palaces in Nigeria for the Resilience of Cultural Heritage and Identity in a Cultural Milieu; Universiti Teknologi Malaysia: Skudai, Malaysia, 2018.

36. Cecchini, S.; Suardo, L.S. Historic house museums in Italy: A new frontier for conservation. In Proceedings of the International Conference ICOM DEMHIST-ARRE, Compiègne and Versailles, Compiegne, France, 7-11 October 2014.

37. Kim, C.-S. The development of attitudes to historic conservation-From eurocentrism to cultural diversity. Archit. Res. 2010, 12, 25-32.

38. Barassi, S. The Modern Cult of Replicas: A Rieglian Analysis of Values in Replication; Tate Papers: London, UK, 2007.

39. Riegl, A. The modern cult of monuments: Its essence and its development. Hist. Philos. Issues Conserv. Cult. Herit. 1996, 69, 83.

40. Gubser, M. Time and history in alois riegl's theory of perception. J. Hist. Ideas 2005, 66, 451-474. [CrossRef]

41. Riegl, A. The Modern Cult of Monuments: Its Character and Its Origin; MIT Press: Cambridge, MA, USA, 1982.

42. Bold, J.; Larkham, P.; Pickard, R. Authentic Reconstruction: Authenticity, Architecture and the Built Heritage; Bloomsbury Publishing: London, UK, 2017.

43. Haspel, J. Contrast versus context: A conflict between the authenticity of the pastand the authenticity of the present? In Conservation and Preservation: Interactions between Theory and Practice: In Memoriam Alois Riegl (1858-1905): Proceedings of the International Conference of the ICOMOS International Scientific Committee for the Theory and the Philosophy of Conservation; Polistampa: Vienna, Austria, 2008; pp. 1000-1017.

44. Tomaszewski, A. From Athens 1931 to Venice 1964: History and actuality. In Conservation and Preservation: Interactions between Theory and Practice: In Memoriam Alois Riegl (1858-1905): Proceedings of the International Conference of the ICOMOS International Scientific Committee for the Theory and the Philosophy of Conservation; Polistampa: Vienna, Austria, 2008; pp. 1000-1008.

45. Iamandi, C. The charters of Athens of 1931 and 1933: Coincidence, controversy and convergence. Conserv. Manag. Archaeol. Sites 1997, 2, 17-28. [CrossRef] 
46. Schädler-Saub, U. Teoria e metodologia del restauro: Italian contributions to conservation in theory and practice. In Conservation and Preservation: Interactions between Theory and Practice: In Memoriam Alois Riegl (1858-1905): Proceedings of the International Conference of the ICOMOS International Scientific Committee for the Theory and the Philosophy of Conservation; Polistampa: Vienna, Austria, 2008; pp. 1000-1014.

47. Matero, F.G. Loss, Compensation, and Authenticity: The Contribution of Cesare Brandi to Architectural Conservation in America; PennDesign, Historic Preservation: Philadelphia, PA, USA, 2007.

48. Barassi, S. Dreaming of a universal approach: Brandi's theory of restoration and the conservation of contemporary art. In Conservation: Principles, Dilemmas and Uncomfortable Truths; Butterworth-Heinemann: Oxford, UK, 2009; (This paper was presented in London on September 24 at the seminar-Conservation: Principles, Dilemmas and Uncomfortable Truths).

49. About ICOMOS [Internet]. International Council on Monuments and Sites. 2011. Available online: https://www. icomos.org/en/about-icomos/mission-and-vision/history?showall=\&start=1 (accessed on 15 March 2019).

50. Dushkina, N. The challenge of change and the 20th-century heritage. In Conservation and Preservation: Interactions between Theory and Practice: In Memoriam Alois Riegl (1858-1905): Proceedings of the International Conference of the ICOMOS International Scientific Committee for the Theory and the Philosophy of Conservation; Polistampa: Vienna, Austria, 2008; pp. 1000-1013.

51. Cunnington, P. Change of Use: The Conversion of Old Buildings; Alpha Books: London, UK, 1988.

52. Cantacuzino, S. Re-Architecture: Old Buildings/New Uses; Abbeville Press: New York, NY, USA, 1989.

53. Brand, S. How Buildings Learn: What Happens after They're Built; Penguin books: Melbourne, Australia, 1995.

54. De Arce, R.P. Urban Transformations and the Architecture of Additions; Routledge: London, UK, 2014.

55. Conejos, S. Designing for Future Building Adaptive Reuse; Bond University Australia: Gold Coast, Australia, 2013.

56. Wilkinson, S.; Remøy, H.; Langston, C. Sustainable Building Adaptation: Innovations in Decision-Making; John Wiley \& Sons: Hoboken, NJ, USA, 2014.

57. Yazdani Mehr, S.; Holden, G.; Skates, H. Adding more by using less: Adaptive reuse of woolstores. In Proceedings of the SBE16 Sydney: International High-Performance Built Environments Conference 2017, Sydney, Australia, 17-18 November 2017; p. 180.

58. Bullen, P.A. Adaptive reuse and sustainability of commercial buildings. Facilities 2007, 25, 20-31. [CrossRef]

59. Ellison, L.; Sayce, S. Assessing sustainability in the existing commercial property stock: Establishing sustainability criteria relevant for the commercial property investment sector. Prop. Manag. 2007, 25, 287-304. [CrossRef]

60. Kincaid, D. Adapting Buildings for Changing Uses; Spon Press: London, UK; New York, NY, USA, 2002.

61. Ruskin, J. Seven Lamps of Architecture; JM Dent and Sons: London, UK, 1907.

62. Athens Charter, D. The Athens charter for the restoration of historic monuments. In Proceedings of the 1st International Congress of Architects and Technicians of Historic Monuments, Athens, Greece, 21-30 October 1931.

(C) 2019 by the author. Licensee MDPI, Basel, Switzerland. This article is an open access article distributed under the terms and conditions of the Creative Commons Attribution (CC BY) license (http:/ / creativecommons.org/licenses/by/4.0/). 